\title{
Report maps perils of warming
}

As the US Senate gears up to debate the latest incarnation of proposed climate legislation next week, a blue-ribbon panel has released what it hopes will be a definitive guide to the consequences of climate change for lawmakers and the public. In offering a degree-by-degree breakdown of the potential impacts of temperature change, the report aims to highlight the effects of stabilizing greenhouse gases at a chosen target level. Yet few are optimistic that the report will influence the fate of the scaled-back climate bill, which would cap emissions from electricity utility companies.

The report ${ }^{1}$, from the US National Research Council (NRC), sets out the consequences - from streamflow and wildfires to crop productivity and sea level rise - of different greenhouse-gas emissions scenarios. It also concludes that once the global average temperature warms beyond a certain point, Earth and future generations will be stuck with significant impacts for centuries or millennia.

Previous assessments tended to tie predictions to specific years or concentrations of carbon dioxide in the atmosphere. But because no one knows the course of future carbon dioxide emissions, this approach amplifies the uncertainties. The NRC report instead sets out the effect of each additional degree of warming, whenever that might happen. "There are some very important future impacts of climate change that could be quantified somewhat better than we previously thought," says Susan Solomon, a senior scientist at the National Oceanic and Atmospheric Administration in Boulder, Colorado, who chaired the report committee.

For example, the report shows that each $1^{\circ} \mathrm{C}$ of warming will reduce rain in the southwest of North America, the Mediterranean and southern Africa by 5-10\%; cut yields of some crops, including maize (corn) and wheat, by $5-15 \%$; and increase the area burned by wildfires in the western United States by $200-400 \%$. The report also points out that even if the atmospheric concentration of carbon dioxide is stabilized, the world will continue to warm for decades. If concentrations rose to 550 parts per million, for example, the world would see an initial warming of $1.6^{\circ} \mathrm{C}$ - but even if concentrations stabilized at this level, further warming would leave the total temperature rise closer to $3^{\circ} \mathrm{C}$, and would persist for millennia.

Deep cuts in carbon dioxide emissions would be needed throughout this century to avoid this long-term warming, something recognized in the American Power Act proposed by Senator John Kerry (Democrat, Massachusetts) and Senator Joe Lieberman (Independent, Connecticut). The bill aims to reduce emissions by $17 \%$ below 2005 levels by 2020 and by more than $80 \%$ by 2050 .

"The report says an $80 \%$ cut is meaningful," says Jay Gulledge, director of the science and impacts programme at the Pew Center on Global Climate Change in Arlington, Virginia. “I've never seen that stated before, but it is based on the best calculations for the carbon cycle."

Besides synthesizing data included in the Fourth Assessment Report released by the Intergovernmental Panel on Climate Change in 2007, the NRC report includes new information. For example, carbon-dioxideinduced warming is expected to be nearly irreversible for at least 1,000 years, according to two studies published in 2008 and 2009 (refs 2,3). "There is more certainty [in this report] than we've seen before," says Steve Cohen, executive director of the Earth Institute at Columbia University in New York City. "It is blunt, direct and clear. Unlike the IPCC reports you don't see any hedge words."

"The science is top notch, but hey've also done a better job of packaging the information in a useful manner," adds Gulledge. "It makes it clear that emissions that occur today really have knock-on effects that go on for centuries and beyond, which is something many decision-makers don't grasp yet."

But will the report have much of an effect on lawmakers' votes? “'The debate over the climate bill is caught up in the mid-term elections and the struggle for power. It doesn't have a lot to do with science or even facts," says Cohen.

Hannah Hoag

1. Climate Stabilization Targets: Emissions, Concentrations, and Impacts over Decades to Millennia Committee on Stabilization Targets for Atmospheric Greenhouse Gas Concentrations, National Research Council (National Academies, 2010); available at: go.nature.com/nWFU7m

2. Matthews, H. D. \& Caldeira, K. Geophys. Res. Lett. 35, L04705 (2008).

3. Solomon, S., Plattner, G.-K., Knutti, R. \& Friedlingstein, P. Proc. Natl Acad. Sci. USA 106, 1704-1709 (2009). 